\title{
Effects of Covid-19 Related Government Budget Shortfall on Funding and Provision of Essential Public Services
}

\author{
Stephen Kwamena Aikins \\ University of South Florida
}

This study investigates COVID-19 related budget revenue losses in US local governments, and their effects on funding and provision of essential public services such as EMS, healthcare, firefighters, police, welfare and public housing services. A survey was sent to county and city governments to learn about their revenue losses for fiscal year 2020 and their effects on funding and service provision. Results show budget revenue loss significantly impacts funding cuts for essential services and is most impactful on welfare and public housing services. Additionally, although funding cuts significantly influence levels of services provided, aid from federal government restrains the extent of funding cuts and the influence of cuts on EMS and healthcare. The findings imply intergovernmental transfers play a pivotal role in averting deep cuts that could be detrimental to saving lives during a crisis. Furthermore, funding availability is key to maintaining appropriate levels of services to help care for the sick and protect the vulnerable in society.

Keywords: budget, COVID-19, local government, public services, revenue loss, funding cuts

\section{INTRODUCTION}

This study investigates the extent of COVID-19 related budget revenue losses in US county and municipal governments, the effects of the budget shortfalls on funding of public services, and how such funding policies affect the level of services provided. Following the onset of the COVID-19 pandemic, many county and city governments in the United States implemented mitigation policies aimed at containing the virus, including stay at home orders, lockdown, physical distancing and restaurants opened for delivery only. These policies not only exerted economic toll on many local jurisdictions, but also unleashed budget revenue loss for numerous local governments, resulting in concerted efforts to roll back resources available for the provision of some government services. For the purpose of this study, budget revenue is defined as the aggregate of all revenues including revenues from local income tax, property tax and sales tax included in the local government budget.

Some scholars have studied evidence of fiscal responses to COVID-19 from local governments and nonprofits (Maher et al. 2020), financial resilience of English local governments in the aftermaths of COVID-19 (Ahrens \& Ferry 2020), and budgeting and employee stress evidence from COVID-19 (Bedford et al. 2020). Others have studied COVID-19 challenges regarding state and local government finances (Felix 2020), state and local government finances in COVID-19 era (Gordon et al 2020), and outcome of COVID-19 on local government budgets (Young 2020). Although these studies make significant contribution to the study of the impacts of COVID-19, the effects of budget shortfalls on cutback of specific essential services, and the level of those services provided has gained little attention. Our study fills this 
gap by dwelling on the theories of cutback management and fiscal stress, to investigate not only the extent of COVID-19 imposed budget revenue loss in fiscal year 2020, but also the impact of the budget shortfall on funding cuts for selected essential public services, and how such funding cuts affected the provision of those services to help manage the COVID-19 pandemic.

The essential services included in this study are the first responder services of Firefighters and Emergency Medical Services (EMS), as well as Healthcare, Police, Welfare and Public Housing services. The above named services were chosen for the study because these services have been central to many citizens' wellbeing during government's fight against COVID-19 as many citizens, especially low income and vulnerable populations, depend on them. For example, many people in vulnerable communities, which are most impacted by the pandemic, depend on public housing and stand the risk of being homeless in the event funding reductions for public housing services impact government's ability to provide those services. Additionally, workers in some of these public services face high risk of exposure to COVID-19 and its variants which could be exacerbated by funding reductions, and ultimately impact service provision. In the next section, we discuss in detail how crucial the management of these essential services is to the fight against the pandemic and the potential results of funding reduction in the face of budget shortfalls.

\section{MANAGING PROVISION OF ESSENTIAL SERVICES DURING COVID-19}

COVID-19 has not only changed the tasks of many public sector workers, but has placed a lot of demands for public services provided by firefighters, police, EMS, healthcare, welfare and public housing to cope with both the public health and the financial impacts of the pandemic in the midst of dwindling resources stemming from local government budget shortfalls.

\section{Firefighters and EMS First Responder Services}

Those employed as firefighters and EMS workers play important roles to further government goals and objectives during the pandemic, but are at greatest risk for COVID-19 infection because they are often first line of healthcare response for patients experiencing complications. Additionally, first responders may be exposed to COVID-19 asymptomatic patients who make emergency calls for reasons other than COVID19 (Ling et al., 2020). This implies the need for effective management of their operations through adequate funding. Budget revenue loss that leads to funding reduction could deprive first responders of adequate financial resource for needed equipment, put the lives of first responders in danger and hamper their ability to provide much needed services to save lives, thereby jeopardizing the level of services in terms of availability and responsiveness to emergency services. Given this situation, it is crucial to know whether these first responder services are spared in cutback decisions during the pandemic, and the extent to which budget revenue loss influence funding reduction for firefighters and EMS services.

\section{Police Law Enforcement Services}

Governments typically enact measures, such as social distancing, isolation, quarantine, travel restrictions and contact tracing to protect the health of residents during a pandemic (Rothstein, 2015). Law enforcement personnel such as police officers are often tasked with explaining and enforcing these measures in the community (Rothstein, 2015). This means Police officers and staff are also often directly or indirectly involved in managing pandemic response through their public safety duties and have a higher risk of getting infected (Bates, 2020). The COVID-19 mitigation policies implemented by many local governments to protect the population and slow the spread of the virus are often controlled and enforced by police, creating additional service demand for law enforcement agencies (Laufs et al., 2020) on top of maintaining law and order and neighborhood policing (Bonkiewicz \& Ruback, 2012), which are performed under strain of resources (Stogner et. al.,2020). The strained resources imply the need for adequate funding in order to be able to provide the needed level of services. Despite this reality, it is possible that police services will take some cut as a result of budget revenue loss during the pandemic. However, to what extent does budget revenue loss impact funding cuts for police service? 


\section{Healthcare Services}

COVID-19 has placed heightened job demand on healthcare workers in a manner not seen in numerous decades, implying the need for effective healthcare management practices such as adequate staffing and resource provision to ensure occupational safety. This has tested the psychological and emotional wellbeing of these workers as patient loads continued to increase and healthcare workers got infected with COVID19 due to resource constraints, contributing to burnout among healthcare workers (Hall, 2020). Job demandresource theory (Bakker \& Demerouti, 2014) argues that when job demands increase while job resources (e.g. technical equipment to operate) and personal resources (e.g. optimism) suffer, we may expect lower work engagement (Hakanen et. al., 2006), greater burnout (Bakker et al., 2005), greater sickness-related absenteeism (Clausen et all., 2012) and lower job performance (Bakker et al., 2005). Therefore, given the increased job demand in healthcare following the pandemic, we should expect that if budget revenue loss leads to healthcare funding reductions, it will limit the ability of healthcare personnel to obtain needed equipment for quality operations.

The US Healthcare system was overstretched in 2020 following the onset of the pandemic, and continues to be stretched in 2021 as a result of the Delta variant, making abundantly clear the inadequacy of resources including staffing in many health facilities. Additionally, healthcare workers such as physicians, nurses and other staff risk their personal health each time they come into contact with COVID19 patients, and this is made worse if they are not adequately funded to procure needed tools such as personal protective equipment (Adams, 2020). The physical and psychological well-being of healthcare workers have been tested as patient loads continued to increase and healthcare workers got infected with COVID-19 and its variants due to resource constraints, contributing to burnout among healthcare workers (Hall, 2020). Therefore, the increased job demand in healthcare services following the pandemic calls for adequate funding, the lack of which could limit service provision to help curtail the effects of the pandemic. It is therefore important investigate whether budget revenue loss affects funding decisions for healthcare during the pandemic, and if so, the extent to which the revenue shortfall influences funding reduction for healthcare.

\section{Welfare Services for the Needy}

The COVID-19 pandemic and its variants have exacerbated the systemic inequalities experienced by marginalized populations in many societies. These vulnerable populations need social safety net to protect them in times of critical need. In recognition of this, welfare administrators in in many advanced countries have been processing large numbers of requests for social support (Cohen, 2020). Welfare services are therefore essential for the survival of vulnerable communities due to the differential effects of the pandemic on those of different classes and races in the United States and other advanced world (Bryant et al., 2020). Consequently, if budget revenue loss results in local government funding cuts policies that affect welfare services, it could reduce the availability of welfare services and responsiveness to the need of vulnerable populations. However, individuals on welfare are among the vulnerable population and tend not to have organized interest groups that influence policy outcomes. Given the lack of strong organized interest groups for the vulnerable, is it likely that budget revenue loss will impact funding for welfare service? If so, to what extent do funding cuts for welfare affect the level of welfare services provided?

\section{Public Housing for the Needy}

People living in low resource areas, including racial and ethnic minorities who cannot get accommodation need public housing services to provide them shelter and minimize exposure to the pandemic. Research shows that before the pandemic, almost half of African Americans and elderly were rent burdened (Urahn et. al., 2018). Due to financial resource constraints, these rent burdened individuals reallocated household funds to pressing issues such as food, electricity and immediate health concerns such as medications (Jones \& Grigsby-Toussaint, 2020) thereby risking their ability to afford rents and rendering them vulnerable to homelessness. Although the CARES Act of 2020 provided one-time economic impact payments of up to $\$ 1,200$, and $\$ 600$ per week of unemployment benefits as a result of COVID-19, these payments were temporary and did not address the problems of housing affordability of the vulnerable in 
society (Jones \& Grigsby-Toussaint, 2020). Additionally, although the US Centers for Disease Control and Prevention extended the moratorium on evictions to give breathing space to renters affected by the pandemic, this was not meant to be permanent. Based on the above, it can be argued that funding adequacy is crucial to ensure provision of adequate public housing to the needy during the pandemic. However, like welfare recipients, individuals in public housing are among the vulnerable population and tend not to have strong organized interest groups that influence policy outcomes. Given that public housing is one of those services that receive funding from federal government, is it less likely that local government budget revenue loss will significantly impact funding cut for public housing, and if so, to what extent?

\section{THEORETICAL FRAMEWORK}

Given the unanswered questions above, we dwell on the theories of cutback management, fiscal stress and budget tightening to explain how budget revenue loss could impact funding cuts for essential public services. Crisis imposed budget shortfalls lead to uncertainty, ambiguity and lack of controllability due to the short time needed to respond (Bundy et. al., 2017; Pearson \& Claire, 1988). Consequently, immediate response to crisis by many local governments tends to be rigid and risk averse (Sitkin \& Pablo, 1992) resulting in cutback of budgetary resources for provision of public services.

\section{Cutback Management Theories}

Rigid response to fiscal stress often entails cutback management which was first studied by Levine $(1978 ; 1979)$ in his seminal work which outlined the causes and responses to organizational decline. Levine (1979) defines cutback management as managerial initiatives or interventions in leading "organizational change toward lower levels of resource consumption and organizational activity." Levine, Rubin and Wolohojian (1981) conducted empirical investigation into four local government responses to revenue reduction and concluded that deeper, long-lasting revenue declines mostly result in targeted program elimination and employee layoffs, whereas short-term less steep revenue declines are mostly managed with across-the-board cuts. These cutback approaches are predicated by funding reductions stemming from the budget revenue shortfalls. In a survey of cutback management strategies in eight Mid-Atlantic and Eastern states, Klase and Dougherty (2008) concluded the evidence supports the phased in model of Levine, Rubin and Wolohojian (1981).

In recent years, two competing theories on local response to fiscal stress that have emerged are the theory of austerity urbanism and the theory of pragmatic municipalism. Proponents of austerity urbanism argue local response to fiscal stress follows national austerity and privatization (Gray \&Bradford 2018; Lowndes \& Gardner 2016; Web \& Bywaters 2018) whereby upper levels of government push budget cutting down to local authorities while concurrently opening up provision of public services to private sector participation (Clifton 2014). Proponents of pragmatic municipalism believe local governments balance the pressures of fiscal stress against community needs (Cipeku et al. 2016; Labao et al., 2014) and maintain delivery of public services through alternative revenue sources and alternative service delivery mechanisms (e.g. Aldag et al. 2019; Kim \& Warner 2016).

The above arguments imply that in the views austerity urbanism theorists, local governments facing budget revenue loss will be forced to cut funding for essential services such as first responder services, healthcare, welfare and public housing. However, unlike the austerity urbanism theorists, the pragmatic municipalism theorists believe local governments do not necessarily reduce funding for essential public services during budget shortfall but rather, maintain service delivery through alternate funding mechanisms. We take the view of the austerity urbanism theorists and argue that budget revenue loss as a result of COVID-19 pandemic will be an important determinant of funding cuts for essential services such as fire, EMS, police, healthcare, welfare and public housing services. However, given the crucial nature of EMS respondent services and healthcare services in a pandemic, it is also likely that other funding sources such as revenue received from federal and state governments may reduce the influence of budget revenue loss on funding cuts for these two services compared to the cuts for firefighters, police, welfare and public services. 


\section{Fiscal Stress, Revenue Loss and Budget Tightening}

Research shows that during fiscal stress, organizations become more concerned with efficiency and conservation of resources in their short-term responses to the crisis (Becker et al., 2016; Bedford et al., 2020; Hopwood, 2009). In tightening budget control as a result of revenue loss, senior managers become less tolerant of deviations from the budget (Van der Stede, 2001) and organizations place more emphasis on resource allocation (Becker et al., 2016; Bedford et al; 2020). It is widely known that budget shortfalls in times of fiscal stress force many county and municipal governments to reduce resources made available for the provision of certain public services. Budget revenue from taxes constitutes the pillar on which most government provision of services rest. In the third quarter 2019 alone, combined state and local government revenues for property, sales and gross receipts, and income taxes was $\$ 337$ billion - an increase of 5.6 percent from \$319 billion in the same quarter of 2018 (US Census Bureau, 2019). Property tax remains an important stable source of revenue for local governments to fund public services (Shuford \& Young, 2000) including first responder services, while sales tax constitutes some of the reliable sources of funding for many local operating budgets.

Government's ability to provide first responder public services such as fire and EMS services, as well as police, healthcare, welfare and public housing services requires sustainable budget revenue to adequately fund those services at the expected level. In the context of pandemic response, financial resource constraints such as budget shortfalls and revenue loss form income tax, property tax and sales tax limit local governments' ability to fund the buying of personal protective equipment and paying of first responders and other essential workers to help minimize control of the pandemic. In line with the arguments of cutback management theory and the austerity urbanism theorists, we argue that in the face of budget revenue loss, government is constrained in funding essential public services. While there is likely to be positive relationships between budget revenue loss and funding cuts for firefighters, police, welfare and public housing services, the impacts of budget revenue loss on EMS respondents and healthcare services are likely to be negative due to the crucial nature of these services, and potential fiscal aid from upper levels of government during a pandemic. Based on the above, our hypotheses are stated as follows:

H1: Budget revenue loss will be positively related to funding cuts for firefighters, police, welfare and public housing services.

H2: Budget revenue loss will be negatively related to funding cuts for EMS and healthcare services.

\section{METHODOLOGY}

This study was in the form of an online survey research. The link to the survey was sent to a stratified random sample of 1,000 local government officials in the United States and 245 of them completed the survey, representing a 25 percent response rate. The survey was conducted in August 2020 through October 2020. Local government officials were chosen as the unit of analysis because they are responsible for managing various aspects of local government operations, including service provision and financial management. Additionally, these officials are responsible for making and implementing policies that affect both the day to day running of their jurisdictions and cutback management stemming from specific mitigation measures against the COVID-19 pandemic.

Nineteen percent of the respondents are in the Northeast region of the United States, 21 percent are in the Southeast, 20 percent are in the Midwest, 18 percent are in the Southwest, and 22 percent are in the West. This distribution implies that respondents were evenly spread in all five regions of the United States. Thirty eight percent of the respondents are city managers and mayors, 13 percent are county administrators and managers, 22 percent are finance directors, 16 percent are treasurers, and the remaining 11 percent are other government officials. Jurisdictions of all sizes were represented. Fifty seven percent of the respondents have populations of less than 50,000, 27 percent have populations between 50,000 and 200,000, 7 percent have populations between 200,000 and 350,000, 3 percent have populations between 350,000 and 500,000 , and 6 percent have populations above 500,000. 
The survey questionnaire were designed to measure variables in each of the following broadly defined categories: budget revenue loss in fiscal year (FY) 2020, income tax revenue loss in FY 2020, property tax revenue loss in FY 2020, sales tax revenue loss in FY 2020, and funding reductions in FY 2020 for each of the following public services included in the study: Firefighters, EMS, Police, Healthcare, Welfare and Public Housing. We sought to determine how funding cut actions for each of the above-named essential services are impacted by budget revenue loss. Therefore, our dependent variables of interest are funding cuts for each of Firefighters Service, Police Service, EMS, Healthcare, Welfare and Public Housing services. Our independent variable of interest is Budget Revenue Loss. Due to the fact that budget revenue is derived from revenues from taxes such as income tax, property tax and sales tax, and that there is the high likelihood of correlation between these revenue sources, we performed multicollinearity test to determine any correlation between our dependent variable and income tax revenue, property tax revenue and sales tax revenue and included these three revenue sources as control variables in our study.

Budget Revenue Loss, Income Tax Revenue Loss, Property Tax Revenue Loss and Sales Tax Revenue Loss variables were all measured on a seven point scale by asking respondents to select from the following answers what they estimate to be their governments' percentage loss of revenue in FY 2020: No Effect; Less Than $5 \% ; 5 \%-9 \% ; 10 \%-14 \% ; 15 \%-19 \% ; 20 \%-24 \%$; and $25 \%$ or More. The results in Table 3 shows significant correlation between the independent and control variables. Additionally, since aid from upper levels of government may influence funding cuts for essential services to combat COVID-19, funding received from Federal and State governments were also included in the multicollinearity test and as control variables. Funding from Federal and State governments were all measured on a seven point scale by asking respondents to select from the following answers what they estimate to be their percentage of FY 2020 budget received from each of Federal and State governments: Less Than 5\%; 5\% - 9\%; 10\% - 14\%; 15\% $19 \% ; 20 \%-24 \% ; 25 \%-29 \% ; 30 \%$ or More.

Funding cuts for Fire Service, Police Service, EMS, Healthcare, Welfare and Public Housing variables were measured by asking respondents to check Yes or No whether their local governments reduced annual budgeted allocations for those public services. For example, funding reduction for EMS was measured by asking respondents to check Yes or No whether their local governments reduced annual budget allocation for the functions of EMS services as a result of budget shortfall stemming from COVID-19. The relationship between funding reduction for each essential service and the level of that service provided was measured by asking respondents to check Yes or No whether they believe funding reduction for each essential service affected the availability and responsiveness to the public need for that service.

The data was analyzed using several logit regression models that tested the relationships Budget Revenue Loss has with funding reductions for Firefighters, Police, EMS, Healthcare, Welfare and Public Housing services. All the control variables were also regressed against funding reduction for each of the selected essential services. Kerlinger (1986) noted that a potential extraneous variable can be controlled by including it as another attribute, an observed variable, in the study. By considering the extraneous variables in their own right, we were able to determine how they interact with the independent variables of interest and the extent to which they influence our independent variables. Descriptive statistics were also used to analyze the loss of budget revenue, income tax revenue, property tax revenue, sales tax revenue, as well as funding reduction for each of the public services included in the study. Chi-Square test of relationship was used to test the relationship between funding reduction for each public service and the level of that service provided.

Logit regression allows a researcher to perform a regression-like analysis of data with dichotomous dependent variable (Walsh, 1987). Logit regression models may be used to analyze and forecast relations of the dependent dichotomic variable and independent variables measured at any scale, in order to avoid conceptualization and complexity problems associated with other models. Logit modeling uses maximum likelihood procedures that are not dependent on the normality assumptions of classical multiple regression for either the independent or dependent variables (DeMaris, 1992). Furthermore, logit analysis is designed for a binary response (Mendenhall \& Sincich, 1989). In applying logit regression, the dichotomic forecast values will never exceed 1 and will never be below 0 . The model therefore measures the natural logarithm of the odds or the log odds of falling into one of two discrete categories on some variable of interest 
(DeMaris, 1992). Given that our dependent variables have binary dichotomous measures, logit is the most appropriate model for analyzing our dependent variables of interest.

Our model estimate for the parameters in the logit regression is:

$$
\mathrm{Y}=\left[\exp \left(a+b_{1} X_{1}+b_{2} X_{2} \ldots b_{n} X_{n}\right)\right] /\left[1+\exp \left(a+b_{1} X_{1}+b_{2} X_{2} \ldots b_{n} X_{n}\right)\right]
$$

where $\mathrm{Y}=$ the dependent variable

$\exp =$ the base of the algorithm exponential function

$\mathrm{a}=$ constant (or intercept) of the model

$b_{i}=$ the parameters (or coefficients of the predictors) of the model, and

$\mathrm{X}_{\mathrm{i}}=$ the predictors of the model

\section{RESEARCH FINDINGS}

We performed reliability analysis to determine the extent to which the variables measured were free from error and therefore yield internal consistency. The Cronbach coefficient for all the variables measured had an alpha coefficient above 0.743 , which suggests adequate internal consistency.

\section{Budget Revenue Loss in FY 2020 and Revenue From Federal and State Governments}

Table 1 shows the frequency distribution of responses to the questions on estimated percentage loss of FY 2020 budget revenue, income tax revenue, property tax revenue and sales tax revenue. As can be seen from Table 1, 30 percent of respondents said their jurisdictions had estimated budget revenue loss of less than 5 percent in FY 2020 as a result of COVID-19, 29 percent of the jurisdictions had between a 5 percent and 9 percent budget revenue loss, and 21 percent had a revenue loss between 10 percent and 14 percent. Additionally, 8 percent of the jurisdictions had between 15 percent and 19 percent revenue loss. This implies that 87 percent of the jurisdictions had up to a 19 percent budget revenue loss due to the impacts of the COVID-19 pandemic.

TABLE 1

\section{PERCENTAGE LOSS OF FY 2020 BUDGET AND TAX REVENUES}

\begin{tabular}{|l|l|l|l|l|l|l|l|l|l|l|}
\hline & \multicolumn{8}{|c|}{ Estimated Percentage Loss of FY 2020 Revenue } & \\
\cline { 2 - 13 } & $\begin{array}{l}\text { No } \\
\text { Effect }\end{array}$ & $\begin{array}{l}\text { Less } \\
\text { Than } \\
5 \%\end{array}$ & $\begin{array}{l}5 \% \\
- \\
9 \%\end{array}$ & $\begin{array}{l}10 \% \\
- \\
14 \%\end{array}$ & $\begin{array}{l}15 \% \\
- \\
19 \%\end{array}$ & $\begin{array}{l}20 \% \\
- \\
24 \%\end{array}$ & $\begin{array}{l}25 \% \\
\text { or } \\
\text { More }\end{array}$ & N/A & $\begin{array}{l}\text { Total } \\
\%\end{array}$ & N \\
\hline $\begin{array}{l}\text { FY 2020 Budget Revenue } \\
\text { Loss }\end{array}$ & 2 & 30 & 29 & 21 & 8 & 6 & 4 & - & 100 & 245 \\
\hline $\begin{array}{l}\text { FY 2020 Income Tax } \\
\text { Revenue Loss }\end{array}$ & 25 & 18 & 29 & 5 & 1 & 5 & 2 & 15 & 100 & 245 \\
\hline $\begin{array}{l}\text { FY 2020 Property Tax } \\
\text { Revenue Loss }\end{array}$ & 49 & 36 & 8 & 5 & 1 & 1 & - & - & 100 & 245 \\
\hline $\begin{array}{l}\text { FY 2020 Sales Tax } \\
\text { Revenue Loss }\end{array}$ & 14 & 23 & 27 & 12 & 6 & 7 & 11 & - & 100 & 245 \\
\hline
\end{tabular}

Table 1 also shows eighteen percent of jurisdictions had less than 5 percent income tax revenue loss, 29 percent had between 5 percent and 9 percent revenue loss, and 5 percent had between 10 percent and 14 percent revenue loss. This means 52 percent had up to 14 percent income tax revenue loss. Thirty six percent of the jurisdictions had less than 5 percent of property tax revenue loss, 8 percent had between 5 percent and 9 percent revenue loss and 5 percent had between 10 percent and 14 revenue loss. The means 59 percent 
of the jurisdictions had up to 14 percent revenue loss. Finally, twenty three percent of the jurisdictions had less than 5 percent sales tax revenue loss, 27 percent had between 5 percent and 9 percent revenue loss, 12 percent had between 10 percent and 14 percent revenue loss, 6 percent had between 15 percent and 19 percent revenue loss and 7 percent had between 20 percent and 24 percent revenue loss. This implies 89 percent of the jurisdictions had up 24 percent revenue loss.

In terms of funds from upper levels of government, results of our analysis revealed 71 percent of jurisdictions received less than 5\% of their FY 2020 revenue from federal government, 15 percent received between $5 \%$ and $9 \%$ of their revenue from federal government, 5 percent received between $10 \%$ and $14 \%$ of their revenue from federal government and another 5\% received between 20 and $24 \%$ of their revenue from federal government. Forty seven percent of jurisdictions received less than 5\% of their FY 2020 revenue from state government, 14 percent received between $5 \%$ and $9 \%$ of their revenue from state government, 18 percent received between $10 \%$ and $14 \%$ of their revenue from state government and 14 percent received $25 \%$ or more of their FY 2020 revenue from state government.

\section{Funding Cuts for Public Services}

Table 2 shows the frequencies of responses to questions posed on funding reductions for public services in FY 2020 due to the budget shortfalls from COVID-19. The findings in Table 2 shows the highest percentage of jurisdictions (49\%) cut funding for Police service in FY 2020, followed by Fire (42 percent), Healthcare (42 percent), EMS services (40 percent), Welfare (37\%) and Public Housing (34\%).

TABLE 2

FUNDING CUTS FOR PUBLIC SERVICES IN FY 2020 DUE TO COVID-19

\begin{tabular}{|l|l|l|l|l|l|l|}
\hline \multirow{3}{*}{ Public Service } & \multicolumn{6}{|l|}{ Reduced Funding in FY 2020} \\
\cline { 2 - 7 } & Yes & No & \multicolumn{4}{l|}{ Total } \\
\cline { 2 - 7 } & Frequency & Percent & Frequency & Percent & Percent & N \\
\hline Firefighter Service & 102 & 42 & 143 & 58 & 100 & 245 \\
\hline Police & 119 & 49 & 126 & 51 & 100 & 245 \\
\hline EMS & 98 & 40 & 147 & 60 & 100 & 245 \\
\hline Healthcare & 102 & 42 & 143 & 58 & 100 & 245 \\
\hline Welfare & 91 & 37 & 154 & 63 & 100 & 245 \\
\hline Public Housing & 83 & 34 & 162 & 66 & 100 & 245 \\
\hline
\end{tabular}

In addition to the above, this study sought to answer whether Budget Revenue Loss is related to funding cuts for essential public services while controlling for the effects of the control variables. Table 3 shows the correlation matrix for the multicollinearity test we conducted. It is noteworthy from Table 3 that Budget Revenue Loss is significantly related to all the control variables. The correlation matrix shows Percentage Losses in Income Tax, Property Tax and Sales Tax are directly related to Budget Revenue Loss, and so are the Percentages of Revenue Received from both Federal and State governments. Also noteworthy is the fact that, Percentage Loss in Income Tax is significantly related to all the other control variables. 
TABLE 3

CORRELATION MATRIX AMONG INDEPENDENT VARIABLES

\begin{tabular}{|c|c|c|c|c|c|c|c|}
\hline & & 1 & 2 & 3 & 4 & 5 & 6 \\
\hline 1 & Percent Loss of Budget Revenue & 1 & & & & & \\
\hline 2 & $\begin{array}{l}\text { Percent Loss of Income Tax } \\
\text { Revenue }\end{array}$ & $.433 * * *$ & 1 & & & & \\
\hline 3 & $\begin{array}{l}\text { Percent Loss of Property Tax } \\
\text { Revenue }\end{array}$ & $.374 * * *$ & $.379 * * *$ & 1 & & & \\
\hline 4 & $\begin{array}{l}\text { Percent Loss of Sales Tax } \\
\text { Revenue }\end{array}$ & $.456^{* * *}$ & $.400 * * *$ & .087 & 1 & & \\
\hline 5 & $\begin{array}{l}\text { Percent of Revenue from Federal } \\
\text { Government }\end{array}$ & $.226^{* * *}$ & $.302 * * *$ & .075 & $.239 * * *$ & 1 & \\
\hline 6 & $\begin{array}{l}\text { Percent of Revenue from State } \\
\text { Government }\end{array}$ & $.158 * *$ & $.206 * * *$ & .039 & -.002 & $.349 * * *$ & 1 \\
\hline
\end{tabular}

Note: $* *=$ Significant at $.05 ; * * *=$ Significant at .001

\section{Impact of Budget Revenue Loss on Funding Cuts}

The next stage of the analysis examined the extent to which Budget Revenue Loss impacts funding reductions for the essential services over and above the influence of the control variables. We hypothesized that 1) Budget Revenue Loss will be positively related to funding cuts for Firefighters, Police, Welfare and Public Housing Services, and 2) Budget Revenue Loss will be negatively related to funding cuts for EMS and Healthcare services. Table 4 shows six binary logistic (logit) regression models of the effects of Percent of Budget Revenue Loss and our control variables on our dependent variables - Reduced Firefighter Funding, Reduced Police Funding, Reduced EMS funding, Reduced Healthcare Funding, Reduced Welfare Funding, and Reduced Public Housing Funding.

Results of the analyses shown in Table 4 confirm both hypotheses 1 and 2. Regarding hypothesis 1 , Table 4 reveals statistically significant positive relationships between Percent Loss of Budget Revenue and funding cuts for Firefighters, Police, Welfare and Public Housing, while controlling for the influence of Percent Loss of Income Tax Revenue, Percent Loss of Property Tax Revenue and Percent Loss of Sales Tax Revenue, as well as Revenue Received from Federal Government and Revenue Received from State Government. The results also show while Percent Loss of Budget Revenue is negatively related to Reduced EMS Funding and Reduced Healthcare Funding, the relationship with Reduced EMS Funding is statistically significant while that with Reduced Healthcare Funding is not. 
TABLE 4

REGRESSION RESULTS OF EFFECTS OF REVENUE LOSS ON FUNDING

\begin{tabular}{|c|c|c|c|c|c|c|}
\hline $\begin{array}{l}\text { Independent and Control } \\
\text { Variables, Coefficient } \\
\text { and Fitness Tests }\end{array}$ & $\begin{array}{l}\text { Reduced } \\
\text { Firefighter } \\
\text { Funding }\end{array}$ & $\begin{array}{l}\text { Reduced } \\
\text { Police } \\
\text { Funding }\end{array}$ & $\begin{array}{l}\text { Reduced } \\
\text { EMS } \\
\text { Funding }\end{array}$ & $\begin{array}{l}\text { Reduced } \\
\text { Healthcare } \\
\text { Funding }\end{array}$ & $\begin{array}{l}\text { Reduced } \\
\text { Welfare } \\
\text { Funding }\end{array}$ & $\begin{array}{l}\text { Reduced } \\
\text { Public } \\
\text { Housing } \\
\text { Funding }\end{array}$ \\
\hline $\begin{array}{l}\text { Percent Loss of Budget } \\
\text { Revenue }\end{array}$ & $\begin{array}{l}.261 * * \\
(.153)\end{array}$ & $\begin{array}{l}.350 * * * \\
(.331)\end{array}$ & $\begin{array}{l}.250^{* *} \\
(.125)\end{array}$ & $\begin{array}{l}.246 \\
(.160)\end{array}$ & $\begin{array}{l}.459 * * * \\
(.362)\end{array}$ & $\begin{array}{l}.433 * * \\
(.384)\end{array}$ \\
\hline $\begin{array}{l}\text { Percent Loss of Income } \\
\text { Tax Revenue }\end{array}$ & $\begin{array}{l}.558 * * \\
(.230)\end{array}$ & $\begin{array}{l}.508 * * * \\
(.252)\end{array}$ & $\begin{array}{l}-.378 \\
(.316)\end{array}$ & $\begin{array}{l}.137 * * \\
(.296)\end{array}$ & $\begin{array}{l}.372 * * \\
(.243)\end{array}$ & $\begin{array}{l}-.090 \\
(.077)\end{array}$ \\
\hline $\begin{array}{l}\text { Percent Loss of Property } \\
\text { Tax Revenue }\end{array}$ & $\begin{array}{l}.084 * * \\
(.043)\end{array}$ & $\begin{array}{l}.156^{* *} \\
(.021)\end{array}$ & $\begin{array}{l}.024 * * \\
(.019)\end{array}$ & $\begin{array}{l}-.124 \\
(.137)\end{array}$ & $\begin{array}{l}.308 \\
(.131)\end{array}$ & $\begin{array}{l}.087 * * \\
(.124)\end{array}$ \\
\hline $\begin{array}{l}\text { Percent Loss of Sales } \\
\text { Tax Revenue }\end{array}$ & $\begin{array}{l}.490 * * \\
(.244) \\
\end{array}$ & $\begin{array}{l}.102 \\
(.016)\end{array}$ & $\begin{array}{l}.161 \\
(.113) \\
\end{array}$ & $\begin{array}{l}.349 \\
(.156)\end{array}$ & $\begin{array}{l}.214 * * * \\
(.173)\end{array}$ & $\begin{array}{l}.130 * * \\
(.120)\end{array}$ \\
\hline $\begin{array}{l}\text { Percent of Revenue from } \\
\text { Federal Government }\end{array}$ & $\begin{array}{l}-.185^{* * *} \\
(.018)\end{array}$ & $\begin{array}{l}-.456 \\
(.294)\end{array}$ & $\begin{array}{l}-.437 * * * \\
(.314)\end{array}$ & $\begin{array}{l}-.395 * * * \\
(.208)\end{array}$ & $\begin{array}{l}-.458 * * \\
(.113)\end{array}$ & $\begin{array}{l}-.259^{* *} \\
(.096)\end{array}$ \\
\hline $\begin{array}{l}\text { Percent of Revenue from } \\
\text { State Government }\end{array}$ & $\begin{array}{l}-.341^{* *} \\
(.109)\end{array}$ & $\begin{array}{l}.087 \\
(.016)\end{array}$ & $\begin{array}{l}-.337 * * \\
(.214)\end{array}$ & $\begin{array}{l}-.372 * \\
(.082)\end{array}$ & $\begin{array}{l}.069 \\
(.073)\end{array}$ & $\begin{array}{l}.167 \\
(.112)\end{array}$ \\
\hline $\begin{array}{l}\text { Omnibus Test of Model } \\
(\mathrm{P}>\text { Chi-Square })\end{array}$ & $25.269 * *$ & $29.016^{* *}$ & $23.337 * * *$ & $27.036 * * *$ & $37.227 * *$ & $33.801 * *$ \\
\hline $\begin{array}{l}\text { Hosmer and Lemeshow } \\
\text { Test }(\mathrm{P}>\text { Chi-Square })\end{array}$ & $13.950 *$ & $18.423 *$ & $11.770 *$ & $17.662 *$ & $21.023 *$ & $19.004 *$ \\
\hline -2 Log Likelihood & 26.187 & 30.665 & 36.245 & 43.824 & 58.119 & 49.800 \\
\hline Cox and Snell R Square & .789 & .702 & .586 & .795 & .711 & .583 \\
\hline Nagelkerke R Square & .856 & .752 & .623 & .877 & .758 & .667 \\
\hline
\end{tabular}

Note: $*$ Significant at $.10 ; * *=$ Significant at $.05 ; * * *$ Significant at .001. Standard errors are in parentheses.

In addition to the above findings, it is important to note that Percent Loss of Budget Revenue did not affect each dependent variable equally, although it is significantly related to most of them. For example, Percent Loss of Budget Revenue was most impactful on Reduced Welfare Funding $(\beta=.459)$, and Reduced Public Housing Funding $(\beta=.433)$, compared to Reduced Firefighters Funding $(\beta=.261)$. The results also show Percent Loss of Income Tax Revenue is the most important determinant of Reduced Firefighters Funding $(\beta=.558)$ followed by Percent Loss of Sales Tax Revenue $(\beta=.490)$, with Percent Loss of Property Tax Revenue being the least determinant $(\beta=.084)$. This means while about 56 percent of the variation in funding reduction for firefighters is explained by per unit change in percentage loss of income tax revenue, only 8 percent of the variation is explained by per unit change in property tax revenue loss. Similarly, per unit change in income tax revenue loss accounts for almost 51 percent change in funding reduction for police service $(\beta=.508)$.

The test results reveal that the Percent of Revenue Received from Federal Government is significantly and inversely related to Reduced Funding for Firefighters, EMS, Healthcare, Welfare and Public Housing. Additionally, Percent of Revenue from State Government is significantly and inversely related to Reduced Funding for Firefighters, EMS and Healthcare services, implying higher federal and state government funding restrains funding cuts for these essential services. Our finding also reveals the most important restraint on EMS funding reduction is revenue from federal government. While per unit change in percent of revenue received from federal government results in about 44 percent change in the restraint on EMS 
funding cut $(\beta=-.437)$, about 34 percent restraint in EMS cuts $(\beta=-.337)$ is caused by per unit change in percent of revenue received from state government. Additionally, the percent of revenue received from federal government has the highest impact on healthcare funding cuts among all the control variables. This is demonstrated by the fact that a per unit change in the percent of revenue received from federal government results in almost 40 percent change regarding restraint on healthcare funding reduction $(\beta=$ .395), compared to the 37 percent change, the second highest, in the restraint on healthcare funding reduction $(\beta=-.372)$ caused by per unit change in state government funding.

As can be seen in Table 4, the $\mathrm{P}$ values of the Omnibus Tests of Coefficient are significant at .001 for two models (Reduced Funding EMS Funding, and Reduced Healthcare funding), and at .05 for the other four models, implying there are significant differences between the Log-likelihoods of the baseline models and each of our six models. Consequently, each one of our models is an improvement over the baseline model. Table 4 also shows the $\mathrm{P}$ values of the Hosmer and Lemeshow Chi-Square tests for each model is significant at .10, indicating a good fit since the rule of thumb is that $\mathrm{P}$ values of 0.05 or lower for this particular test constitute a poor fit. Table 4 also shows the model on Reduced EMS funding has the highest pseudo R-Square values, with Cox and Snell R-Square being .795 and Nagelkerke R-Square being. 877 .

\section{Relationship Between Spending Cut and Service Provision}

Table 5 shows the Chi-Square test of relationships between the Funding cut for each of the six essential services and the level of each service provided. As shown in Table 5, there is a statistically significant relationship between funding reduction for four of the essential services and the level of each service provided.

TABLE 5

RELATIONSHIP BETWEEN FUNDING REDUCTION AND SERVICE PROVISION

\begin{tabular}{|c|c|c|c|}
\hline \multirow[b]{3}{*}{ Funding Reduction Public Service Areas } & \multicolumn{3}{|c|}{ Service Level Impacted } \\
\hline & \multicolumn{3}{|c|}{ Pearson Chi-Square } \\
\hline & Value & $\mathrm{df}$ & $\begin{array}{l}\text { Asymp. Sig. } \\
\text { (2-sided) }\end{array}$ \\
\hline Fire Service & 4.373 & 3 & $\mathbf{0 . 0 3 7}$ \\
\hline Police Service & 12.397 & 3 & 0.000 \\
\hline EMS & 0.035 & 3 & 0.852 \\
\hline Healthcare & 1.129 & 3 & 0.218 \\
\hline Welfare & 6.479 & 3 & 0.011 \\
\hline Public Housing & 4.912 & 3 & $\mathbf{0 . 0 2 7}$ \\
\hline
\end{tabular}

The relationship between funding cut for police service and the level of police service provided is the strongest $(\mathrm{P}=0.000)$, followed by the relationship between funding reduction for welfare and the level of welfare service provided (P 0.011), the relationship between funding reduction for public housing and the level of public housing services $(\mathrm{P}=0.027)$ and the relationship between spending cut for firefighter service and the level of firefighter service provided $(\mathrm{P}=0.037)$. The table also shows nonsignificant relationships between funding cuts for each of EMS and healthcare and the level of each of these services provided. This may be due to the strong influence of the percent of revenue received from federal government being a significant restraint on funding cut for these services.

\section{DISCUSSION}

The results of our study show 87 percent of the jurisdictions who responded to the survey had up to a 19 percent budget revenue loss due to the impacts of the COVID-19 pandemic, 52 percent had up to a 14 percent income tax revenue loss; 59 percent of the jurisdictions had up to a 14 percent property tax revenue 
loss, and 89 percent had up a 24 percent sales tax revenue loss. Following the above-mentioned revenue shortfalls, 49 percent of the jurisdictions cut funding for police, the highest among all the services included in this study. Additionally, 42 percent cut funding for fire service and healthcare. Funding for EMS and welfare services were also cut by 40 percent and 37 percent of respondents respectively. It is unknown whether the numerous calls in many parts of the country during summer 2020 to defund the police had anything to do with the relatively high percentage of jurisdictions that cut funding for police.

The above funding reduction is a consequence of the reality of both the fiscal stress on many local governments, and the fact that many county and city governments had to carry a higher financial burden in dealing with the public health crisis, as they struggled to provide support for their vulnerable citizens at the time when their own-source revenue plummeted. Faced with declining tax revenue on top of expensive new service burdens, many local government budgets experienced extraordinary strain since the start of the COVID-19 pandemic. Fortunately for these local governments, the $\$ 350$ billion "Coronavirus State and Local Fiscal Recovery Fund" included in the \$1.9 trillion American Rescue Plan (ARP) Act of 2021, \$120 billion of which is earmarked for local governments, offered a lifeline. County and city governments could use these dollars to fill in some budget holes and invest this one-time windfall in ways that catalyze inclusive growth and address persistent equity gaps pertaining to vulnerable populations.

The funding provided under the ARP would help to provide needed resources to strengthen policecommunity relations. This is because emergency situations such as pandemics can have a significant impact on police-community relations and public trust in the police in that while effective and successful police response to disasters and emergencies can put people out of harm's way and ensure public safety and wellbeing, ineffective police response due to resource constraints can undermine public trust in the police. Additionally, adequate funding could help to enhance the ability of the police to obtain much needed training and tools to improve police-community relations that have deteriorated in some of our communities in recent times, and to address professional challenges facing law enforcement.

The results of our logit regression models reveal statistically significant positive relationships between budget revenue loss and funding cuts for firefighters, police, welfare and public housing services, and a statistically significant negative relationship between budget revenue loss and spending cut for EMS. This implies as budget revenue loss increased, it is significantly more likely to influence funding cuts for firefighters, police, welfare and public housing services but significantly less likely to impact spending cut for EMS. The inverse relationship between budget revenue loss and funding cut for EMS may be explained by the fact that even in the event of budget shortfall in the pandemic, public officials consider the critical role of EMS service providers as first responders in diagnosing and transporting the sick to the hospital for further treatment.

The evidence from the test result also shows that comparatively, a per unit change in budget revenue loss results in higher percentage change in funding cuts for welfare and public housing - services that the vulnerable need most during a pandemic. However, the test results also shows that funding received from federal government is significantly and inversely related to spending cuts for welfare and public housing as well as firefighters, EMS and healthcare, while state funding also negatively impacts funding reduction for firefighters, EMS and Healthcare. The significance of this finding is that the more intergovernmental assistance from upper levels of government, in particular from the Federal government, the less likely local governments will cut funding for services for the vulnerable in crucial times of need imposed by the pandemic.

As stated earlier, many welfare beneficiaries, who are ethnic minorities and elderly have been hard hit by the pandemic. Additionally, many need housing assistance due to inadequate personal finances. Furthermore, many of these people did not have jobs that could afford them the luxury of working from home - a situation that exacerbated their vulnerability during the pandemic. Consequently, it is obvious that many of them looked up to their respective local governments to provide the needed assistance to cope with the effects of the crisis. Intergovernmental transfers in terms of federal dollars therefore provided much needed cushion to local governments to fund services for the poor during the pandemic.

In addition to welfare and public housing services, firefighter, EMS and healthcare services are all critical to the survival of the sick and the vulnerable in society during the pandemic. Many firefighters and 
EMS personnel who had to respond to COVID-19 related emergency calls put their lives and those of their loved ones at risk by going to provide pre-hospital patient care services. The nature of their work requires adequate provision of financial resources to not only provide them with critically needed personal protective equipment to help minimize the risk of infection, but also motivate them to prevent frustration and disengagement which could render government response to the pandemic ineffective. Federal policy in terms of aid to local governments is therefore critical as evidenced by its restraint on local funding cuts for these essential services during the pandemic.

Our Chi-Square test of relationship reveals significant relationships between funding reduction for each of firefighters, police, welfare and public housing services and the level of each of those services provided in terms of availability and responsiveness to public need for those services. Among these, the association between funding cut for police and level of police service provided is the strongest. However, the relationships between funding reduction for each of EMS and healthcare service and the level of each service provided are weak. It is worth pointing out that, as revealed by the research findings discussed above, revenue received from federal government significantly restrained local government funding cuts for EMS and healthcare services. The weak association could also partly be due the heightened commitment of the health professionals in these two service areas to do their utmost to save lives during the pandemic. Finally, it can be argued that while a significant relationship exists between spending cuts for firefighters, welfare and public housing, and the level of each of those services provided, the restraint of federal aid on funding reduction for these services discussed above may have had some moderating effect on the relationship between funding reduction and the level of services provided.

\section{CONCLUSIONS}

This study found that many local governments experienced substantial revenue loss in taxes as a result of the COVID-19 pandemic. Additionally, budget revenue loss in local government resulted in funding reduction for firefighters, police, EMS, welfare and public housing services which are key essential services at the heart of the fight against the COVID-19 pandemic. However, aid from federal government provided lifeline to local governments and restrained spending cuts for most of these services. This finding is important because adequate budget and funding could enhance government response to the pandemic by enabling local government to procure necessary tools for professionals in these service areas to discharge their duties safely and effectively, to help to reduce the risks of spreading the virus to their families, and to minimize anxieties that could impact their work performance. Additionally, the vulnerable in society that have mostly being impacted by the COVID-19 pandemic rely on welfare and public housing and need effective, well-resourced providers for effective service delivery.

This study is limited in that it did not examine the impacts of specific dollar amounts of funding reduction for each of the public services, neither did it review the impact of other factors such as FTE reduction on the level of the services provided. Additionally, the impact of budget cuts on programmatic reviews and efficiency of operations was outside the scope of this study. These limitations notwithstanding, the findings are useful in that that the effects of funding reductions as a result of COVID-19 on each specific essential service and how federal aid to local governments moderate funding cuts for each of those services has been understudied.

This study has policy and practical implications for public administration. From policy perspective, the findings suggest that intergovernmental transfers to assist local governments during a pandemic and times of fiscal stress do play a pivotal role in averting deep funding cuts that could be detrimental to providing critical public services to fight the crisis and save lives. From practical perspective, the findings reveal that adequate funding availability is key to maintaining an appropriate level of public services to help care for the sick and protect the vulnerable. This will happen if governments implement inclusive policies to address the impacts of the pandemic. 


\section{REFERENCES}

Aldag, A.M., Kim, Y., \& Warner, M.E. (2019). Austerity urbanism or pragmatic municipalism? Local government responses to fiscal stress in New York state. Environment and Planning A: Economy and Space, 51(6), 1287-1305.

Bryant, T., Aquanno, S., \& Raphael, D. (2020). Unequal impact of COVID-19: Emergency Neoliberalism and welfare policy in Canada. Critical Studies, 15, 22-39.

Adams J.G., \& Walls, R.M. (2020). Supporting the health care workforce during the COVID-19 global epidemic. JAMA, 323(15), 1439.

Ahrens, T., \& Ferry, L. (2020). Financial resilience in English local government in the aftermath of COVID-19. Journal of Public Budgeting, Accounting and Financial Management, 32(5), 813823.

Bakker, A.B., \& Demerouti, E. (2014). Job demand-resources theory. In P.Y. Chen \& C.I. Cooper (Eds.), Wellbeing: A complete reference guide, vol. 3, Work and wellbeing (pp. 37-64). Malden, MA: John Wiley \& Sons.

Bakker, A.B., Demerouti, E., \& Euwema, M.C. (2005). Job resources buffer the impact of job demands on burnout. Journal of Occupational Health Psychology, 10(2), 170-80.

Bates, J. (2020). Police departments, sheriff's offices across the U.S. grapple with COVID-19's impact on public safety and their own. Time. Retrieved February 8, 2021, from https://www.sheriffs.org/Police-Departments-Sheriffs-Offices-Across-US-Grapple-COVID-19sImpact-Public-Safety\%E2\%80\%94and-Their-Own

Becker, S.D., Mahlendorf, M.D., Schäffer, U., \& Thaten, M. (2016). Budgeting in times of economic crisis. Contemporary Accounting Research, 33(4), 1489-1517.

Bedford, D.S., Speklé, R.F., \& Widener, S.K. (2020). Budgeting and Employee Stress in Times of Crisis. Evidence from the COVID-19 Pandemic. [Working paper]. Retrieved May 20, 2021, from https://papers.ssrn.com/sol3/papers.cfm?abstract_id $=3749883$

Bonkiewicz, L., \& Ruback, R.B. (2012). The role of the police in evacuations: responding to the social impact of a disaster. Police Quarterly, 15(2), 137-156. https://doi.org/10.177/1098611112442808

Bundy, J., Pfarrer, M.D., Short, C.E., \& Coombs, W.T. (2017). Crises and crisis management: Integration, interpretation, and research development. Journal of Management, 43(6), 1661-1692.

Clausen, T., Nielsen, K., Carneiro, I. G. and Borg, V. (2012). Job demands, job resources and long-term sickness absence in the Danish eldercare services: A prospective analysis of register-based outcomes. Journal of Advanced Nursing, 68(68), 127-136.

Clifton, J. (2014). Beyond hollowing out: Straitjacketing the State. The Political Quarterly, 85(4), 437444.

Cipeku, D., Mussari, R., \& Giordano, F. (2016). Local governments managing austerity: Approaches, determinants and impact. Public Administration, 94(1), 223-243.

Cohen, P. (2020, April 23). Jobless numbers are "Eye-Watering” but understate the crisis. New York Times. Retrieved, August 10, 2021, from https://www.nytimes.com/2020/04/23/business/economy/unemployment-claims-coronavirus.html

DeMaris, A. (1992). Logit modeling practical application. Sage University Paper Series on Quantitative Applications in the Social Sciences, Series No. 07-086. Newbury Park CA: Sage.

Felix, A. (2020). COVD-19 Challenges State and Local Finances. Federal Reserve of Kansas City. Economic Bulletin. Retrieved April 1, 2020, from https://ideas.repec.org/a/fip/fedkeb/87965.html

Gordon, T., Dadayan, L., \& Reuben, K. (2020). State and Local Finances in the COVID-19 Era. https://doi.org/10.17310/ntj.2020.3.05

Gray, M., \& Bradford, A. (2018). The depths of the cuts: The uneven geography of local government austerity. Cambridge Journal of Regions, Economy and Society, 11(3), 541-563.

Hakanen, J.J., Bakker, A.B., \& Schaufeli, W.B. (2006). Burnout and work engagement among teachers. Journal of School Psychology, 43(6), 495-513. 
Hall, H. (2020). The effect of COVID-19 pandemic on healthcare workers' mental health. Journal of American Academic of Physician Assistants, 23(7), 45-48.

Hopwood, A.G. (2009). The economic crisis and accounting: Implications for the research community. Accounting, Organizations and Society, 34(6-7), 797-802.

Jones, A., \& Grigsby-Toussaint, D.S. (2020). Housing stability and the residential context of the COVID19 pandemic. Cities \& Health, pp. 2-3.

Kerlinger, F.N. (1986). Foundations of Behavioral Research (3rd ed.). New York: CBS.

Klase, K., \& Dougherty, M.J. (2008). The impact of performance budgeting on state budget outcomes. Journal of Public Budgeting, Accounting and Financial Management.

Lobao, L., Adua, L., \& Hooks, G. (2014). Privatization, business attraction, and social services across the United States: Local governments' use of market-oriented, neoliberal policies in the post-2000 period. Social Problems, 61(4), 644-672.

Laufs, J., Bowers, K., Birks, D., \& Johnson, S.D. (2020). Understanding the concept of 'demand' in policing: A scoping review and resulting implications for demand management. Policing and Society, pp. 1-24. https://doi.org/10.1080/

Levine, C.H. (1978). Organizational decline and cutback management. Public Administration Review, 38(4), 316-25.

Levine, C.H. (1979). More on cutback management: Hard questions for hard times. Public Administration Review, 39(2), 179-183.

Ling, Z., Xu, X., Gan, Q., Zhang, L., Luo, L., Tang, X., \& Liu, J. (2020). Asymptomatic SARS-CoV-2 infected patients with persistent negative CT findings. European Journal of Radiology, 126, 108956.

Levine, C.H., Rubin, I.S., \& Wolohojian, G.G. (1981). The Politics of Retrenchment: How Local Governments Manage Fiscal Stress. Beverly Hills, CA: Sage Publications.

Lowndes, V., \& Gardner, A. (2016). Local governance under the conservatives: Super austerity, devolution and the 'smarter state'. Local Government Studies, 42(3), 357-375.

Maher, C.S., Hoang, T., \& Hindrey, A. (2020, July/August). Fiscal responses to COVID-19: Evidence from local governments and nonprofits. Public Administration Review, pp. 644-650.

Mendenhall, W., \& Sincich, T. (1989). A Second Course in Business Statistics Regression Analysis ( ${ }^{\text {rd }}$ ed.). San Francisco: Dellen.

Rothstein, M.A. (2015). From SARS to Ebola: Legal and ethical considerations for modern quarantine. Indiana Health Law Review, 12, 227-280.

Shuford, G., \& Young. R. (2000). A report on local government funding: An overview of national issues and trends. Columbia, S.C.: University of South Carolina

Urahn, S.. K., Plunkett, T., Currier, E., Key, C., Biernacka-Lievestro, J., Lake, W., . . Lantz, A. (2018). American families face a growing rent burden. Washington, DC: Pew Charitable Trusts.

US Census Bureau. (2019). Quarterly summary of state and local government tax revenue for third quarter 2019. Retrieved, May 16, 202,1 from https://www.census.gov/content/dam/ Census/library/publications/2019/econ/g19-qtax3-tagged.pdf

Van der Stede, W.A. (2001). Measuring 'tight budgetary control'. Management Accounting Research, 12(1), 119-137.

Sitkin, S.B., \& Pablo, A.L. (1992). Reconceptualizing the determinants of risk behavior. Academy of Management Review, 17(1), 9-38.

Walsh, A. (1987). Teaching understanding and interpretation of logit regression. Teaching Sociology, 15, 178-183.

Webb, C.J.R., \& Bywaters, P. (2018). Austerity, rationing and inequity: Trends in children's and young peoples' services expenditure in England between 2010 and 2015." Local Government Studies, 44 (3), 391-415.

Young, J. (2020). 10 common outcomes of COVID-19 on local government budgets. Retrieved April 28, 2021, from https://icma.org/blog-posts/10-common-outcomes-covid-19-local-governmentbudgets

126 Journal of Management Policy and Practice Vol. 22(4) 2021 